\title{
Editor's Report for the Journal of Political Science Education
}

Victor Asal, University at Albany, Editor-in-Chief

Mitchell Brown, Auburn University, Coeditor

Mark L. Johnson, Minnesota State Community and Technical College, Coeditor

Shane Nordyke, University of South Dakota, Coeditor

Joseph W. Roberts, Roger Williams University, Coeditor

J. Cherie Strachan, Central Michigan University, Coeditor

Mirren Galway, University at Albany, State University of New York, Managing Editor

Jessica Van Saders, University at Albany, State University of New York, Managing Editor

Margaret Bidwell, Roger Williams University, Editorial Assistant

\section{INTRODUCTION}

The editorial team for the Journal of Political Science Education has now been running the journal for the last two years with support from APSA and specifically from Jon Gurstelle, Director of Publishing. In our second year working on the journal the process has gone well and we have a good team of managing editors and editorial assistants at the University at Albany and at Roger Williams University.

\section{and Year Highlights}

Now ending the second year of our running of the journal as an APSA wide journal we have seen submissions go up and authors and readers becoming accustomed to the new sections of the journal we established when we started running the journal (in addition to the existing sections of Scholarship of Teaching and Learning (SoTL) and continuing reviews of Books, Teaching Tools, \& Educational Resources) along with significant and growing interest in the new sections we established both in terms of submissions and positive feedback from comments by readers. The two sections that were added are:

- Political Science Instruction: Submissions should focus on innovative teaching cases that discuss useful pedagogy, including strategies, games, and experiential learning

Table 1

\section{Authors by Gender}

\begin{tabular}{lll} 
Female & Male & Total \\
\hline $34(47 \%)$ & $39(53 \%)$ & 73 \\
\hline
\end{tabular}

Parentheses-Percentage of Total including coauthors, all original submissions in teaching political science to diverse audiences. They should also be organized around real classroom problems and potential solutions. Submissions may range in length from 2,00o-4,00o words.

- Reflections on Teaching and the Academy: Submissions should be from experienced scholar-teachers that focus on reflections of timely and important teaching topics that include transitioning between institutional types, teaching underprepared students, preparing graduating students for teaching careers, and other issues. Submissions may range in length from 1,000-2,00o words.

In this past year we also had a long discussion on the journal having a stronger presence on social media and have recently joined Twitter, like many other academic journals. The twitter handle of the journal is @JPSE_Editors. We plan to invest time in increasing the impact of this feed and increasing the number of followers. After not receiving enough submissions for our special issue last year, we are on track to publish a special issue of JPSE focusing on the use of simulations and games to teach political science. We have also begun to discuss what the specific focus of the next special issue will be and currently our candidate for the topic is failure in teaching and how to handle it. There are two important shifts between our first and second year that we would like to note. The number of manuscripts submitted to the journal has more than doubled in our second year and the number of submissions from women is now close to $50 \%$ of all submissions.

We had productive "meet the editors" roundtables at both the 2017 Annual Meeting and 2018 Annual Meeting. We are also currently working on submitting a list of our

Table 2

Authors by Rank

\begin{tabular}{llllllll} 
Professor & $\begin{array}{l}\text { Associate } \\
\text { Professor }\end{array}$ & $\begin{array}{l}\text { Assistant } \\
\text { Professor }\end{array}$ & Lecturer & Student & $\begin{array}{l}\text { Administration/ } \\
\text { Professional }\end{array}$ & Other & Total \\
\hline $15(21 \%)$ & $9(12 \%)$ & $19(26 \%)$ & $11(15 \%)$ & $12(16 \%)$ & $7(10 \%)$ & $0(0 \%)$ & 73
\end{tabular}

Parentheses-Percentage of Total including coauthors, all original submissions

Table 3

Authors by Country of Submission

\begin{tabular}{lllllllll} 
Australia & Canada & Denmark & Israel & Korea & Sweden & UK & US & Total \\
\hline $1(1.2 \%)$ & $2(2.4 \%)$ & $1(1.2 \%)$ & $1(1.2 \%)$ & $1(1.2 \%)$ & $1(1.2 \%)$ & 4 & 73 & 84 \\
& & & & & & $(4.7 \%)$ & $(86.9 \%)$ & $(100 \%)$ \\
\hline
\end{tabular}

Parentheses-Percentage of Total including coauthors, all original submissions 
Table 4

\begin{tabular}{rlllll}
\multicolumn{2}{c}{$\begin{array}{c}\text { Authors by Type of Institution } \\
\text { College }\end{array}$} & Nonacademic & Private University & Public University & Total \\
\hline July-Sept 2017 & $1(6 \%)$ & $0(0 \%)$ & $8(47 \%)$ & $8(47 \%)$ & 17 \\
\hline Oct-Dec 2017 & $2(11 \%)$ & $0(0 \%)$ & $0(0 \%)$ & $16(89 \%)$ & 18 \\
\hline Jan-March 2018 & $5(24 \%)$ & $0(0 \%)$ & $3(14 \%)$ & $13(62 \%)$ & 21 \\
\hline April-June 2018 & $2(12 \%)$ & $0(0 \%)$ & $4(23 \%)$ & $11(65 \%)$ & 17 \\
\hline Total Percentage & $10(14 \%)$ & $0(0 \%)$ & $15(20 \%)$ & $48(66 \%)$ & $73(100 \%)$
\end{tabular}

Parentheses-Percentage of Total including coauthors, all original submissions

Table 5

Types of Submission

\begin{tabular}{lllll}
$\begin{array}{l}\text { Scholarship of } \\
\text { Teaching and Learning }\end{array}$ & $\begin{array}{l}\text { Political Science } \\
\text { Instruction }\end{array}$ & $\begin{array}{l}\text { Books, Teaching Tools, } \\
\text { and Educational Resources }\end{array}$ & Reflections & Total \\
\hline $33(33.3)$ & $38(38.4 \%)$ & $15(15.2 \%)$ & $13(13.1 \%)$ & 99
\end{tabular}

Parentheses-Percentage of Total, all original submissions

Table 6

\begin{tabular}{llll}
$\begin{array}{l}\text { Manuscript Decision (Original Submissions) } \\
\text { Accepted } \\
\text { Revise and Resubmit }\end{array}$ & $\begin{array}{l}\text { Reject* } \\
\text { Total }\end{array}$ \\
\hline $15(15 \%)$ & $65(66 \%)$ & $19(19 \%)$ & $99(100 \%)$
\end{tabular}

* This is the percentage of all rejected manuscripts, not of all new manuscripts

Parentheses-Percentage of Total, all original submissions

Table 7

\section{Reviewer Statistics}

\begin{tabular}{ll|lll} 
Reviews Invited & Reviews Completed & No Replies & Declines & Assigned/Agreed \\
\hline 812 & $565(70 \%$ of 812$)$ & $63(8 \%$ of 565$)$ & $133(16 \%$ of 565$)$ & $618(76 \%$ of 565$)$ \\
\hline
\end{tabular}

Table 8

Average Reviewer Turnaround Time

\begin{tabular}{ll} 
Editorial Board & Reviewers \\
\hline 27.86 days & 28.79 days \\
\hline
\end{tabular}

editorial board (new, proposed members and any members to retain), to the APSA Council for review. In sum, our team has enjoyed this second year and we are looking forward to continuing the journal's growth and outreach as an APSA-wide journal.

\section{Staffing}

Our staff at the Journal of Political Science Education consists of six coeditors who use a portion of their time to work as a team as well as specifically on their own sections of the journal. Two student managing editors and one editorial assistant work part-time on the journal. Our managing editors from fall 2017 to the end of the spring semester in 2019 are Jessica Van Saders and Mirren Galway. At the end of the spring semester Mirren Galway will continue and we will find a replacement for Jessica Van Saders. Both managing editors are students at the University at Albany, SUNY. Margaret Bidwell, a student at Roger Williams University, is currently serving as editorial assistant and will continue to do so this coming year.

\section{PRODUCTION AND DELIVERY Author Demographics}

The demographic distribution of the Journal of Political Science Education authors are reported in tables 1, 2, 3, and 4. Currently $47 \%$ of our article authors are women-an increase of $14 \%$ over last year; our article authors are spread across different ranks with assistant professors being responsible for more submissions than any other rank, with $26 \%$ of articles, and tenured faculty responsible for $33 \%$ of articles. As one can see from the table 3 , only $13 \%$ of our submissions were from overseas but this is a $3 \%$ increase in international submissions from the previous year.

\section{Content and Treatment of Manuscripts}

Table 5 shows the percentage of articles submitted that were directed at being submitted as original articles (both SoTL and Political Science Instruction sections), review articles, and reflection articles. We should note that the number of manuscripts submitted has risen dramatically from 40 in the first year of the journal to 99 this year-an increase of more than $100 \%$. Table 6 shows the decisions for manuscripts. Our current rejection rate is $19 \%-\mathrm{a}$ rate we hope to increase as we continue to increase our submissions to the journal. Table 7 presents information on reviewer statistics. We should note that the percentage of completed reviews has increased from $63 \%$ in the first year to $70 \%$ this last year. Table 8 is new this year and provides data on average reviewer turnaround time. We have also seen an improvement in time from submission to decision with the average time going from 54.5 days to 45.2 days.

\section{Makeup of the Editorial Board}

Table 9 shows the gender makeup of the editorial board with the board being close 


\section{Table 9}

Ed. Board by Gender

\begin{tabular}{lll} 
Female & Male & Total \\
\hline $12(48 \%)$ & $13(52 \%)$ & 25 \\
\hline
\end{tabular}

Parentheses-Percentage of Total

to evenly made up of men and women. Table 10 shows the distribution of the board by type of institution with most of the board working at public universities. Table 11 shows that almost all of the board is from the United States with two members from the United Kingdom, and one from Slovakia.

\section{Publicity and Outreach}

The editors of the Journal of Political Science Education are working to increase our publicity and outreach. We have asked authors to provide a 50-word blurb and a

Table 10

\section{Editorial Board by Type of Institution}

College

Nonacademic

Private University

Public University $\quad$ Total

$1(4 \%)$

$0(0 \%)$

$7(28 \%)$

$17(68 \%)$

$25(100 \%)$

Table 11

\section{Editorial Board by Country}

\begin{tabular}{lllll} 
Netherlands & Slovakia & UK & US & Total \\
\hline $1(4 \%)$ & $1(4 \%)$ & $2(10 \%)$ & $18(85 \%)$ & $25(100 \%)$ \\
\hline
\end{tabular}

130-character tweet, many of which have been shared on PSNow. We plan to continue to attend each Teaching and Learning and APSA-wide conference to hold "meet the editor" roundtables where we can reach out to potential authors about submitting to the journal. When it is possible, members of our editorial team have organized such events at regional APSA conferences, and we plan on continuing to do so. 